\title{
Population Dynamics of Saissetia oleae (Olivier) (Hemiptera: Coccidae) on Olives
}

\author{
Faiza Ilias $^{1^{*}}$, Fatiha Hammadi² \\ ${ }^{1}$ Center University of Belhadj Bouchaib, Ain Temouchent, Algeria \\ ${ }^{2}$ National Institute of Plant Protection, Tlemcen, Algeria \\ Email: *faizahope@yahoo.fr
}

How to cite this paper: Ilias, F. and Hammadi, F. (2017) Population Dynamics of Saissetia oleae (Olivier) (Hemiptera: Coccidae) on Olives. Open Access Library Journal, 4: e3805.

https://doi.org/10.4236/oalib.1103805

Received: July 4, 2017

Accepted: November 19, 2017

Published: November 22, 2017

Copyright (c) 2017 by authors and Open Access Library Inc.

This work is licensed under the Creative Commons Attribution International License (CC BY 4.0).

http://creativecommons.org/licenses/by/4.0/

(c) (7) Open Access

\begin{abstract}
A preliminary study on fluctuation of black scale, Saissetia oleae (Olivier) (Hemiptera: Coccidae), was carried out in Algeria in order to assess population dynamics and infestation incidence on olive groves. Monitoring was conducted in two years (2014-2015) in three localities in North Algeria. The density of populations has varied from year to year and from region to region. Populations peaked in June, when crawlers emerged after the egg-laying period, and decreased during several months. Additionally, S. oleae can be considered a risky pest of olive groves in Algeria. Therefore, further studies on population dynamics are necessary for a better understanding of its biology in this Algeria.
\end{abstract}

\section{Subject Areas}

Biodiversity

\section{Keywords}

Saissetia oleae, Dynamics, Olive, Region, Generation

\section{Introduction}

Saissetia oleae (Olivier) (Hemiptera: Coccidae), the black scale, is one of the most important pests of olive in the Mediterranean region and of citrus trees. As discussed by Tena [1], Mediterranean black scale generally continues to be a problem in most coastal citrus growing areas of the world. According to Haniotakis [2], black scale is considered a major secondary pest, meaning that it occurs throughout the Mediterranean region, causing damages of major economic importance locally or occasionally. As discussed by Tena [1], the damages are produced when large populations are present; their feeding can cause physiolog- 
ical damage to the host plant through an increase in the transpiration rate and by depletion of nutrients.

In Algeria, as discussed elsewhere [3] [4], Saissetia oleae (Olivier) (Hemiptera: Coccidae), Polliniapollini (Costa) (Hemiptera: Coccidae) and Parlatoriaoleae (Colve'e) (Hemiptera: Diaspididae) represent the most important scale of olive. S. oleae infests leaves and twigs of citrus and olives. Black scale is known by its high reproductive capacity, the number of eggs laid by the scale range from a few hundreds to 4000 as discussed elsewhere [5] [6]. After hatching, the crawlers move out of the egg chamber beneath the mother's body and they wander over the host plant searching for a suitable place to settle, Tena [1]. In Mediterranean countries, this species may have one generation per year, one and a partial second generation, or two complete generations, depending on crop species, nutrition of the tree, agricultural practices, possibly different strains of $S$. oleae, and most importantly, climate as discussed elsewhere [6] [7].

In Algeria, the life cycle of $S$. oleae remains unclear, with the reported number of generations. Moreover, no long-term and area-wide studies have been conducted to determine and compare its life cycle in olive orchards at many regions.

\section{Material and Methods}

\subsection{Experimental Site}

The study was evaluated in the field with data gathered from 2014 and 2015 in three traditional olive groves: 1) Ain Temouchent: $35^{\circ} 19^{\prime} 60^{\prime \prime} \mathrm{N}, 1^{\circ} 4^{\prime} 60^{\prime \prime} \mathrm{W}, 296 \mathrm{~m}$, 2) Mascara: $35^{\circ} 25^{\prime} 0^{\prime \prime} \mathrm{N}, 0^{\circ} 10^{\prime} 0^{\prime \prime} \mathrm{E}, 676 \mathrm{~m}$, (3) SidiBel Abbes: $35^{\circ} 11^{\prime} 38^{\prime \prime} \mathrm{N}$, $0^{\circ} 38^{\prime} 29^{\prime \prime} \mathrm{W}, 483 \mathrm{~m}$, in Algeria. Neither of these olive groves received any chemical treatment during the study. The first orchard of 2 ha was 15 years old, the second of 3 ha was 9 years old and the third of 7 ha was 22 years.

\subsection{Data Collection}

During the years 2014 and 2015, a sample of 40 branches, each $20 \mathrm{~cm}$ in length, was taken monthly and examined to determine the population density of the developmental instars (eggs, crawlers, nymphs and female adults) of five randomly selected olive trees and the relative abundance and the flight dynamics of adult on different olive organs.

The densities of first-instar and second-instar nymphs were calculated on old and young parts. The density was reported on 400 old leaves (10 leaves $\times 40$ branches) and on 200 young leaves (5 young leaves $\times 40$ branches) and the results were given per leaf. For the young branches $(10 \mathrm{~cm}$ length), the averages were calculated per linear meter. For the old branches $(25 \mathrm{~cm}$ length), average numbers were obtained by dividing the crawlers and nymphs found on 40 branches by $1000 \mathrm{~cm}(40 \times 25 \mathrm{~cm})$ to have density by linear meter, as discussed by Ouguas [8].

The spatial distribution of crawlers and nymphs was compared with cardinal directions all the groves. The volume of mature females was compared with the 
three groves and year (2014 and 2015) as main factors.

\subsection{Data Analysis}

One-way analysis of variance (Anona) and Tukey's honestly significant difference (HSD) test $(p<0.05)$ were used to compare the means amond different generations and/or years. Although data were transformed for statistical analysis, means and standard errors based on the original data are presented in figures. Calculations were one with MINITAB 15.

\section{Results}

Figures 1-3 shows the seasonal abundance of the olive scale, $S$. oleae was studied for two successive years from 2014-2015 on three olive groves. The obtained results showed considerable fluctuations in abundance during the year. Populations peaked in summer (June), when crawlers emerged after the egg-laying period in April and May, and decreased during the next several months.

Crawler emergence was relatively synchronized across all groves during the first generation in July. The cumulative percentage of first instars emerged in spring-summer in each grove and year is compared in fig. The second emergence period was observed in the grove of Ain Temouchent was less synchronized and more extended. This period started in September-November and lasted until March as shows Figure 2. In Mascara and SidiBel Abbes groves, Figure 1 and Figure 3 shows one generation that peaked in June. These results due to probably to the climate change with the high temperature during the two years of study.

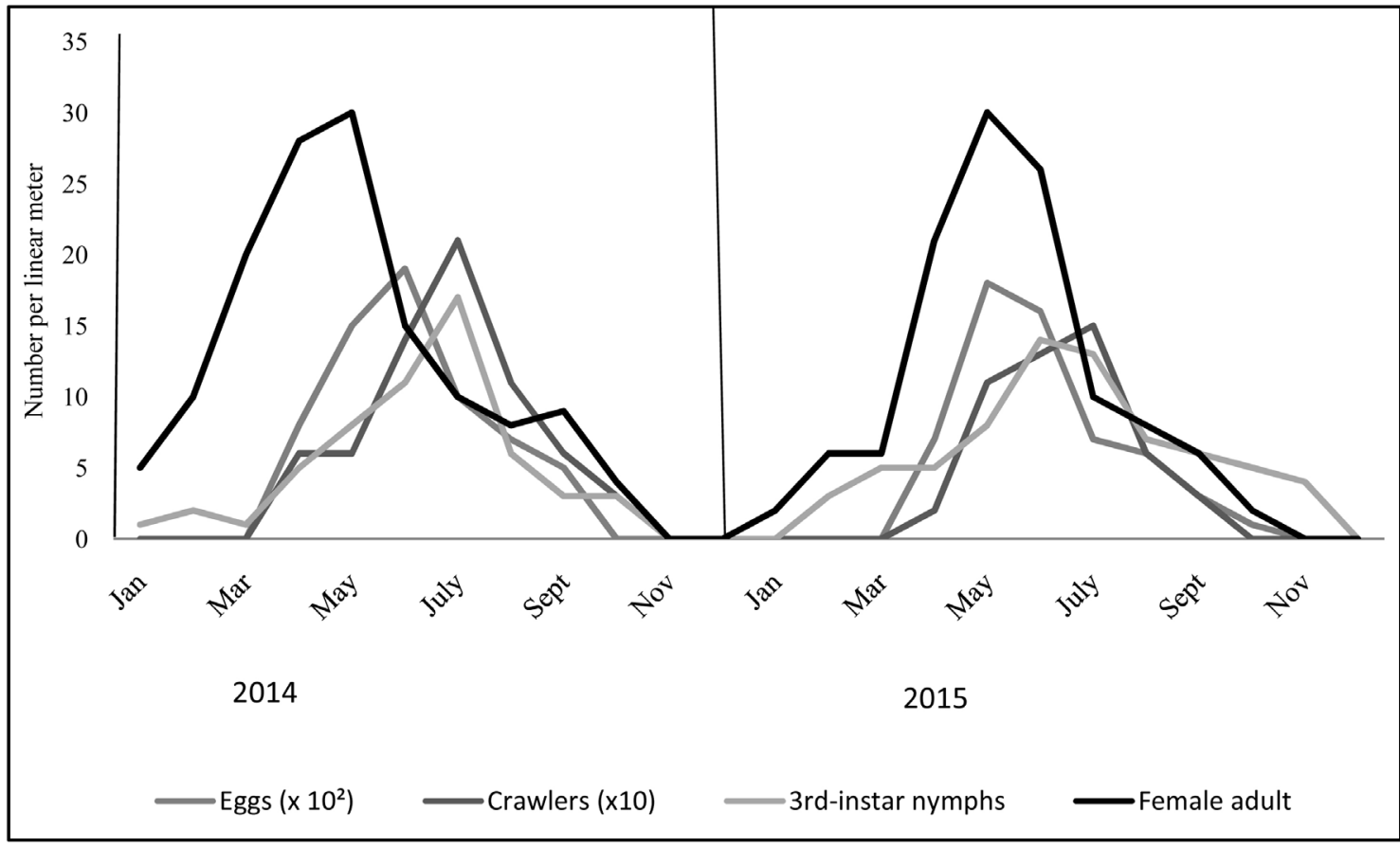

Figure 1. Seasonal trend of the scale Saissetia oleae (Olivier) in SidiBel Abbes orchard. 


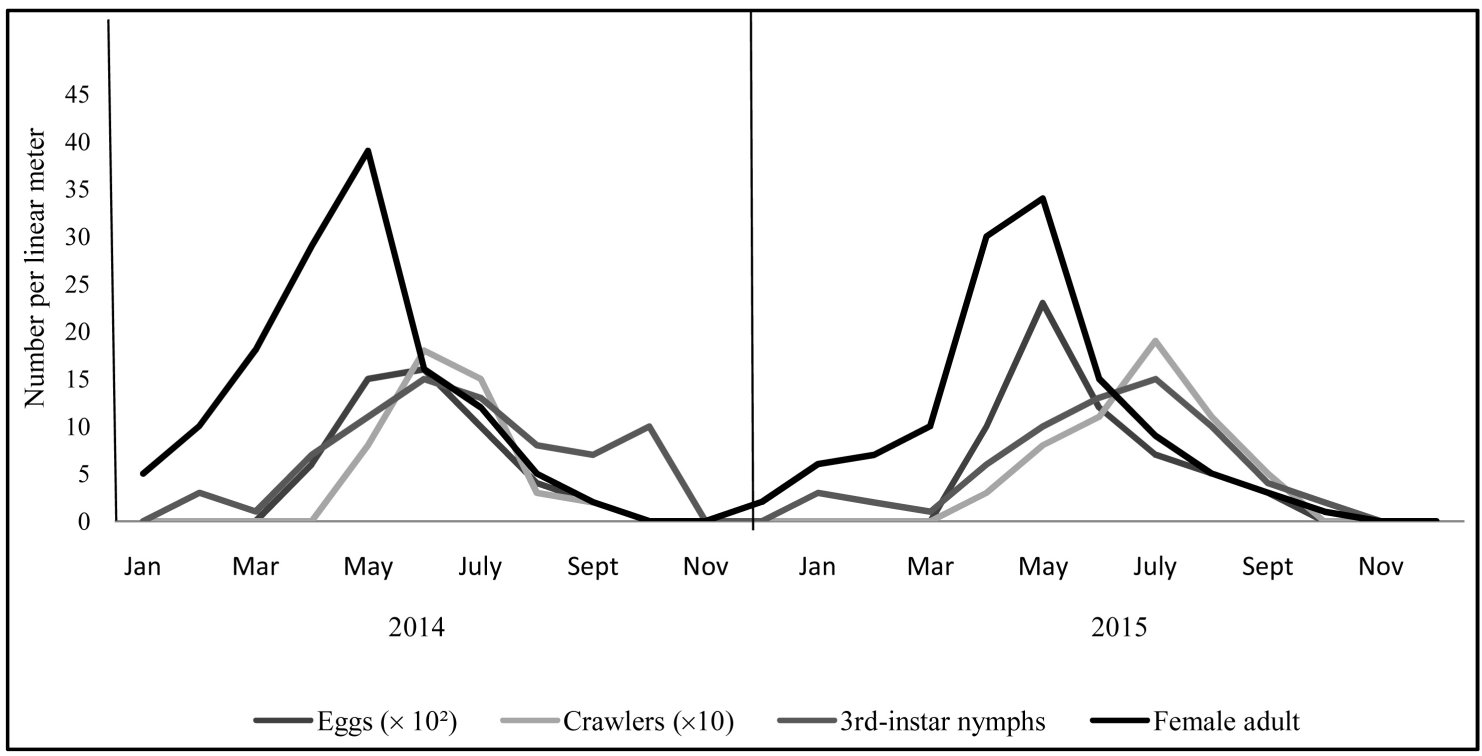

Figure 2. Seasonal trend of the scale Saissetia oleae (Olivier) in Ain Temouchent orchard.

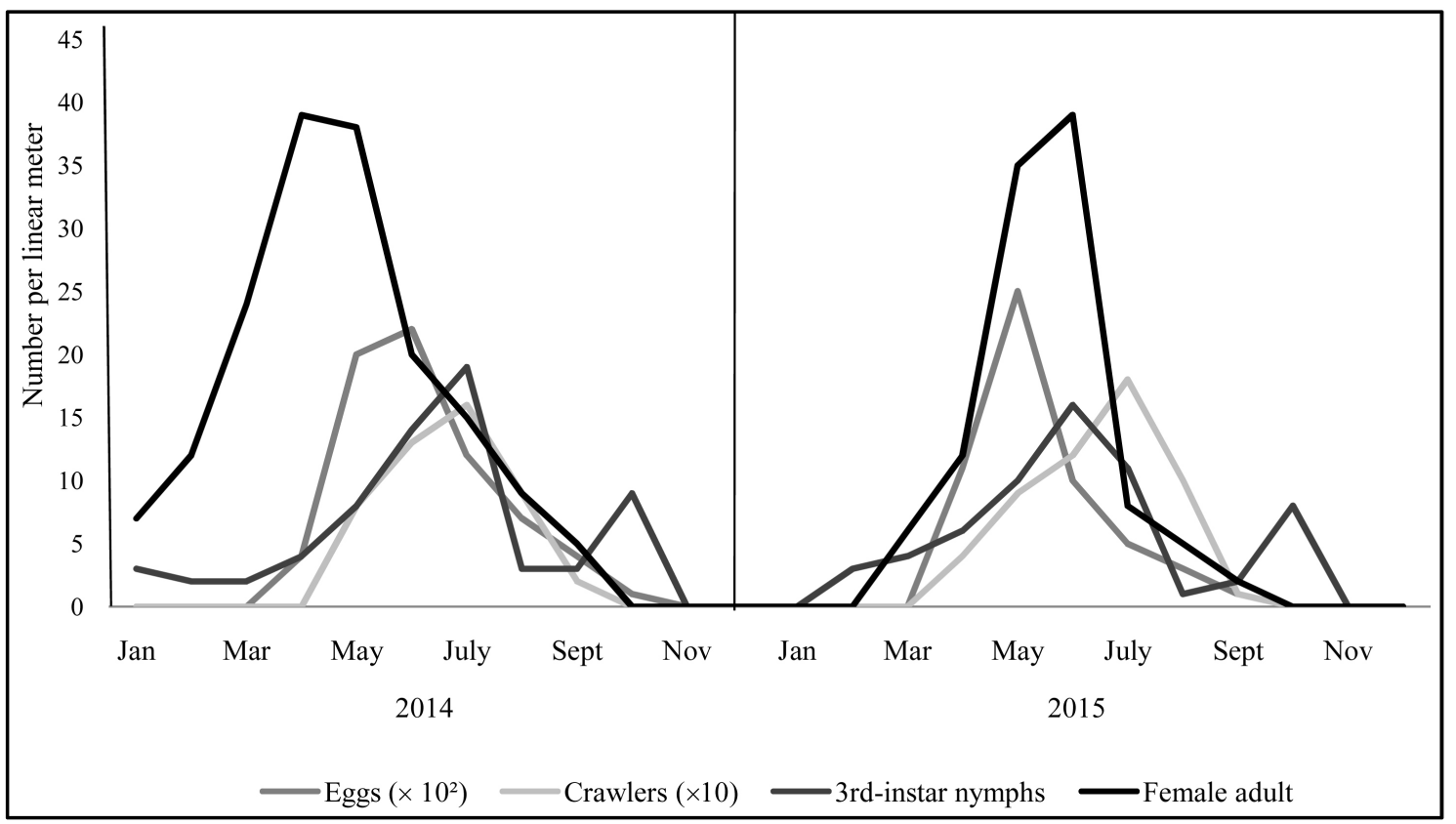

Figure 3. Seasonal trend of the scale Saissetia oleae (Olivier) in SidiBel Abbes orchard.

In the old grove of SidiBel Abbes, the eggs started to be laid in May 2014 and they reached their maximum in July (2245 eggs per linear meter) and did not reappear until May 2015 of next year with a maximum in August (4989 eggs per linear meter). Adult females, they appeared from early January to October in 2014 and appear April until October in 2015.

The crawlers densities are 0.1 to 2.52 in 2014 and 0.3 to 3.1 in 2014. We can note that the duration of different instars was longer in the two years because the rainfall was abundant and so the humidity was suitable for them.

In Ain Temouchent and Mascara groves (the young orchard), eggs appeared 
from Marsh to October in the two years and for the both groves. The maximum number of eggs was about 1896 eggs per linear meter in Mascara and 2341 eggs per linear meter in Ain Temouchent. The crawlers followed the same trend as in the previous orchard. Indeed, the crawlers appeared from Marsh and persisted until November in Mascara and to April until October in Ain Temouchent.

The third-instar nymphs were present in from January to December in the years 2005. As in the old orchard, the adult females were found in surveys conducted between January and November with different peaks; 39 adult females per linear meter in 2014 in Ain Temouchent and 30 adult females perlinear meter in Mascara.

Crawler density present a peak of 4.02 per old leaf as maximum and 3.01 per young leaf and a maximum of 3.3 on old branches and 1.6 on young branches. Figure 4 shows the presence of these instars was concentrated between April and September with a high peak in 2015. Statistically, these densities varied significantly from one organ to another $(\mathrm{P}=0.003)$. These immature instars showed a preference for the young leaves and branches.

Adult females that were collected during the spring and old grove laid a maximum of 3.157 eggs in olives, whereas females that were collected in autumn in young grove laid a maximum of 953.120 eggs. There was a significant relationship between ovipositing female volumes and number of eggs found beneath females as shows Figure 5. Female volume was variable depending on season, region, age and location on the tree.

The spatial distribution of crawlers and nymphs of $S$. oleae according to the cardinal directions of the tree demonstrate that the Center is the preferable

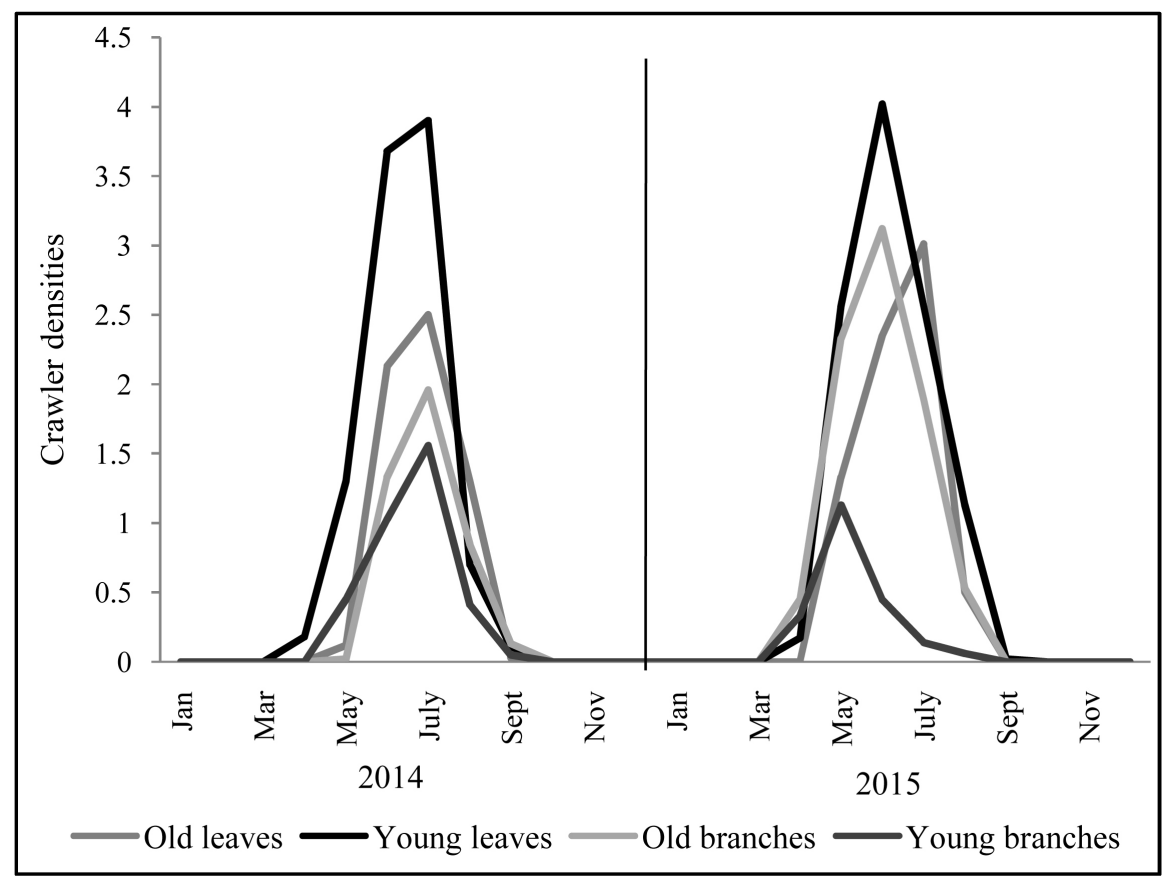

Figure 4. Density of crawlers of the scale Saissetia oleae (Olivier) on old and young leaves per leaf, and on old and young branches per linear meter in three olive orchards. 
direction for the both followed by North, South directions respectively as shows Figure 6. The Center represents 30 crawlers per linear meter $10^{3}$ and 28 nymphs per linear meter $10^{3}$. The East represents the last direction preferred by Crawlers and nymphs with 10 and 11 per linear meter $10^{3}$ respectively.

\section{Discussion}

This study presents the dynamics and densities population structure of $\mathcal{S}$. oleae, including number of generations and crawler emergence periods between 2014 and 2015 in three regions of olive groves in North Algeria.

In this study, $S$. oleae adults appear from April to September or October, because of synchronized and concentrated crawler emergence after the egg laying period in Marsh-May. We suggest that the climate change with the high temperature in summer change or influence the development of $S$. oleae. Our observations are not similar to those of other western Mediterranean authors, most of

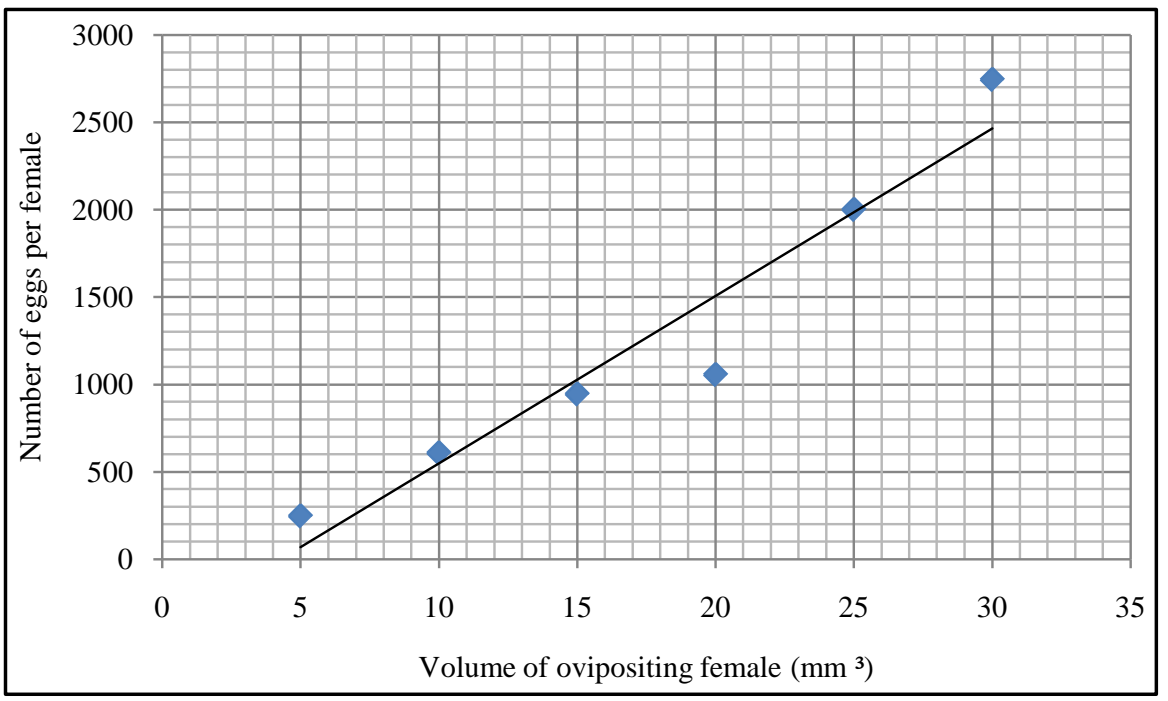

Figure 5. Relationship between number of eggs per female and the volume of ovipositing female of S. oleae in different orchard of olive sampled in Algeria during 2014 and 2015.

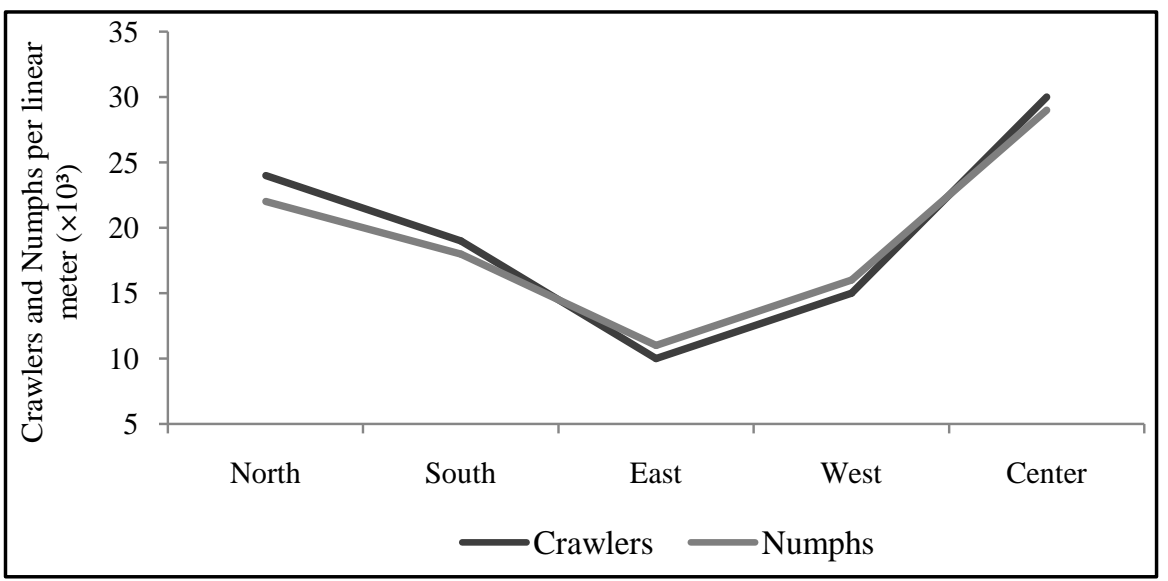

Figure 6. Spatial distribution of $S$. oleae according to the cardinal directions of the tree. 
whom reported crawler emergence in June-July, as discussed elsewhere [1] [8] [9] [10].

In our study, it's a partial second crawler emergence in Ain Temouchent. Tena [1], reported that the second generation is heterogeneous and variable depending on year, crop, and grove.

Saissetia oleae populations exhibited considerable abundance fluctuations during the year. Population density decreased for several months, especially during the summer, because of high mortality of first-instar scales, Tena [1]. Most eggs and crawlers that hatched during the winter perished, as discussed elsewhere [11] [12]. In Spain, Tena [1], demonstrates that low temperatures synchronized the developmental stages present, and consequently, populations were strongly synchronous after the winter.

In our study, crawlers showed a preference for the young leaves and branches. These results are similar to those of Morroco. Ouguas [8], who suggest that young tissues are rich in sap and tender, young crawlers can easily suck the sap. Also, these crawlers remain on the same organ and do not move far away from it as discussed by Paparatti [13]. Crawlers will moult after one month and then migrate to the young stems and branches of the tree, as discussed by Sekkat [14].

A significant relationship between female volume and number of eggs that they contained are beneath their bodies. This relation was also observed by Pereira [10] in olive groves and Tena [1] in olive and citrus groves. The volume of the female represents its potential fecundity more accurately than the number of eggs found in a particular moment as discussed by Tena [1].

$S$. oleae showed a preference to the Center direction. The North, Center and the East are the favorite spot for Parlatoriaziziph scale in Algeria as discussed by Belguendouz [15]. They reported that, larvas, nymphs and femellesadultesprefered the Center and North directions. It's due to the conditions climatiques, microclimatiques of the region and the nutriments elements necessary for the development and reproduction.

Our result showed that climate has a big influence upon scale spread and infestation, it's showed an important level's infestation especially on autumn and spring season, also, young organs are more infested than the old organs. Also, this study showed also, that Saissetia oleae population was very important in the center direction where the humidity is high with low mild temperature and light.

\section{References}

[1] Tena, A., Soto, A., Vercher, R. and Garcia-Mari, F. (2007) Density and Structure of Saissetiaoleae (Hemiptera: Coccidae) Populations on Citrus and Olives: Relative Importance of the Two Annual Generations. Environmental Entomology, 36, 700-706. https://doi.org/10.1093/ee/36.4.700

[2] Haniotakis, G.E. (2005) Olive Pest Control: Present Status and Prospects. Proceedings of the IOBC/WPRS Conference on Integrated Protection of Olive Crops, Chania, 29-31 May 2003.

[3] Moghaddam, M. and Tavaloli, M. (2010) Scale Insects of the Central Zagros Region 
in Iran. Applied Entomology and Phytopathology, 77, 37-38.

[4] Sema, S. and Selma, U. (2010) Scale Insects Species (Homoptera: Coccidea) in the Turkish Republic of North in Cyprus. Turkish Journal of Zoology, 34, 219-224.

[5] Smith, D., Beattie, G.A.C. and Broadley, R. (1997) Citrus Pests and Their Natural Enemies, Integrated Pest Management in Australia. H.R.D.C. D.P.I., Queensland.

[6] Passos de Carvalho, J., Torres, L.M., Pereira, J.A. and Bento, A.A. (2003) A Cochonilha-Negra Saissetiaoleae (Olivier, 1791) (Homoptera-Coccidae). Instituto Nacional de Investigaçao Agraria, Universidade de Tras-os-Montes e alto Douro, Escola Superior Agraria de Bragança.

[7] Panis, A. (1977) Contribución al Conocimiento de la Biología de la "Cochinillanegra de Losagrios” (Saissetiaoleae Olivier). Boletín de Sanidad Vegetal y Plagas, 3, 199.

[8] Ouguas, Y. and Chemseddine, M. (2011) Effect of Pruning and Chemical Control on Saissetiaoleae (Olivier) (Hemiptera, Coccidae) in Olives. Fruits, 66, 225-234. https://doi.org/10.1051/fruits/2011029

[9] Noguera, V., Verdu, M.J., Gomez-Cadenas, A. and Jacas, J.A. (2003) Ciclobiologico, Dinamicapoblacional y Enemigosnaturales de Saissetiaoleae Olivier (Homoptera: Coccidae), en Olivaresdel Alto Palencia (Castellon). Boletín de sanidad vegetal. Plagas, 29, 495-504.

[10] Pereira, J.A.C. (2004) Bioecologia da Cochonilhanegra Saissetiaoleae (Olivier), Naoliveira, em Tra's-os-Montes. PhD Disertation, Unversidade de Tra's-os-Montes e alto Douro, Vila Real, Portugal.

[11] Canard, M. and Laudeho, Y. (1977) Etude d Õunedeuxie 'mege' nerationd Õhiver de Saissetiaoleae Oliv. (Hom.,Coccidae) en Attique (Gre'ce) et de sare'duction par Metaphycuslounsburyi How. (Hym.,Encyrtidae) et Scutellistacynea Motsch. (Hym., Pteromalidae). Fruits, 32, 554-561.

[12] Pucci, C., Salmistraro, D., Forcina, A. and Montanari, G. (1982) Incidenzadeifattoriabioticisullamortalita` della Saissetiaoleae (Oliv.). Redia, 65, 355-366.

[13] Paparatti, B. and Lecanidae (1986) Saissetiaoleae Olivier. In: Arambourg, Y. and Bravo, J., Eds., Traitéd'entomologieoléicole, International Olive Council, Madrid.

[14] Sekkat, A. (1976) Saissetiaoleae Bern. (Homop., Lecanidae), Maladies et ravageurs des plantes cultivées deseases and pests of cultivated plants in Morroco, Rabat, Morroco.

[15] Belguendouz, R., Biche, M., Bekkouche, S. and Louz, S. (2011) The Impact of Parlatoriaziziphi Infestations on Physicochimical Quality of Citrus Fruits. Cas of the Clementine Variety: Citrus Reticulata in Mitidja (Boufarik, Algérie). Integrated Control in Citrus Fruit Crops IOBC/wprs Bulletin, 62, 137-142. 
Submit or recommend next manuscript to OALib Journal and we will provide best service for you:

- Publication frequency: Monthly

- 9 subject areas of science, technology and medicine

- Fair and rigorous peer-review system

- Fast publication process

- Article promotion in various social networking sites (LinkedIn, Facebook, Twitter, etc.)

- Maximum dissemination of your research work

Submit Your Paper Online: Click Here to Submit

Or Contact service@oalib.com 